Open Access

\title{
Appropriation of affordances of multiliteracies for Chinese literacy teaching in Canada
}

Mi Song Kim ${ }^{*}$ and Xiaotong Xing

\author{
*Correspondence: misong.kim@ \\ gmail.com \\ Curriculum Studies, Faculty of \\ Education, University of Western \\ Ontario, 1137 Western Road, \\ London, ON N6G 1G7, Canada
}

\begin{abstract}
Innovative literacy teaching and learning approaches have proved that multiliteracies enables teachers to work with culturally and linguistically diverse (CLD) students. However, few studies have shed light on examining Chinese teachers' understanding and practices of multiliteracies in Canada. To respond to this challenge, this qualitative case study aims to understand how Chinese teachers who pursued multiliteracies graduate studies perceive and implement multiliteracies in teaching young CLD children Chinese literacy in Canada. We investigated narratives of two Chinese teachers to provide useful insights into their lived experiences of multiliteracies for Chinese literacy teaching. A constant comparison approach was adopted to analyze three data sources through narrative analysis: interviews, reflective writings, and curriculum materials. Findings suggest that these teachers actively appropriated affordances of multiliteracies for Chinese literacy teaching in Canada drawing upon graduate courses in multiliteracies. The paper concludes with the pertaining implications to highlight the importance of teacher professional development.

Keywords: Multiliteracies, Multimodality, Design, Chinese literacy teaching,

Affordances
\end{abstract}

\section{Introduction}

Over the past two decades, global connectedness and technological changes have prompted a reconsideration of the traditional literacy curricula and pedagogy, and the roles both teachers and students play (Kalantzis and Cope 2012; Kim 2013; Kim and Rutgers 2018). According to a National Household Survey 2011, the largest source of immigrants in Canada is Asia and the most common language spoken, besides English and French which are the two official languages, is Chinese. Apart from the current significance of Chinese language which triggers governments to encourage their citizens to learn it, many Chinese immigrants in Canada are looking to have their children learn their language by establishing Chinese schools where interested locals can attend as well. At present, Canada has 30 Confucius institutes and classrooms across the country to help familiarize people with Chinese culture and language (Hanban 2015) which is a substantial growth compared to 1899 when the first Chinese school was established by the

(c) The Author(s). 2019, corrected publication 2021 Open Access This article is distributed under the terms of the Creative Commons Attribution 4.0 International License (http://creativecommons.org/licenses/by/4.0/), which permits unrestricted use, distribution, and reproduction in any medium, provided you give appropriate credit to the original author(s) and the source, provide a link to the Creative Commons license, and indicate if changes were made. 
Chinese Consolidated Benevolent Association to help children learn Chinese (Liu and Bebbington 2012).

Students from English-speaking countries are working hard to improve their Chinese literacy, but the literacy teaching methods their Chinese educators are using are lagging behind (Li 2013). One problem is that Chinese teachers have less experience in providing innovative teaching practices and resources for students. For example, Jin and Cortazzi (1998) noted that Chinese teachers have "very little creativity" (p. 756) in teaching young students and are faced with "limitations on resources" (p. 743) they can use for teaching Chinese literacy. This is in line with Albert's (2011) findings that many Chinese teachers followed traditional Chinese literacy teaching methods, which pay more attention to reading and writing skills. Also, the study stated that they rely mainly on a written textbook in classrooms and lack the awareness needed to utilize multimodal resources such as technology tools, movies, or arts into their teaching.

However, to successfully function in the twenty-first century, students need to become multiliterate using multiple communication channels (Cope and Kalantzis 2000; Kalantzis and Cope 2017). Thus, it is important for teachers, in particular teachers of young culturally and linguistically diverse (CLD) children, to help engage them in multimodal literacy practices (Kuby and Vaughn 2015). Relying solely on textual resources (e.g., printed materials) limits the ways students communicate and creatively make meaning. Further, although technological resources have been an essential part of literacy teaching, Chinese teachers of young CLD children do not have appropriate and relevant examples of innovative literacy teaching methods within a similar context from which they can learn and enhance their own classrooms ( $\mathrm{Li}$ et al. 2012; Li et al. 2011). To respond to these challenges, in this paper, we present narratives of two in-service Chinese teachers of young CLD children in their journey with the use multiliteracies that they learned through their master program in Canada. This study was guided by this research question: What are Chinese teachers' lived experiences in implementing multiliteracies in teaching Chinese literacy to young culturally and linguistically diverse (CLD) children in Canada?

\section{Literature review}

By examining existing literature on multiliteracies, we review the importance and effectiveness of implementing multiliteracies to support young CLD children's literacy development.

\section{A pedagogy of multiliteracies for guiding innovative literacy teaching}

From a traditional perspective, literacy often disregards "children's cultural and linguistic resources" to "assimilate them into the fictions of mainstream culture" (Cope and Kalantzis 2014, vii). However, in today's schools, due to the "proliferation of communications channels and media supports" (The New London Group 1996, p. 61) as a result of globalization and technological developments, students are from different cultural and linguistic backgrounds, and this fact makes the current school context diverse with interests and experiences (Kalantzis and Cope 2017). Hence, teachers of young CLD students need to recognize student diversity and draw on differences to create meaning (Makin et al. 2007; Rowe 2013). 
Students are also able to become multiliterate through multiliteracies practices tailored to their specific qualities (Cole and Pullen 2009; Hamston 2006; Mills 2006). Multiliteracies, initiated by the New London Group (NLG) in 1996, refers to "the multiplicity of communications channels and medias, and the increasing saliency of cultural and linguistic diversity" (p. 63). This new approach optimizes the concept of literacy by "emphasizing how negotiating the multiple linguistic and cultural differences in our society is central to the pragmatics of the working, civic, and private lives of students" (p. 60).

In terms of the pedagogy of multiliteracies, there are two main components, design and multimodality (Cope and Kalantzis 2009; The New London Group 1996). First, the design in multiliteracies includes three key elements: Available Designs, Designing, and the Redesigned (The New London Group 1996). Available Designs are the accessible multiple semiotic resources to make meanings; Designing is transforming the meanings on/with the Available Designs, and the Redesigned is the what has been transformed and reproduced through the Designing process (Cope and Kalantzis 2009; The New London Group 1996). Through such designing processes, teachers develop engaging literacy practices which help students including young CLD children become "fully makers and remakers of signs and transformers of meaning" (Cope and Kalantzis 2009, p. 175) by drawing on their diverse cultures and linguistic differences and experiences.

There are four crucial dimensions in multiliteracies pedagogy (The New London Group 1996): Situated Practice, Overt Instruction, Critical Framing, and Transformed Practice. These four components of multiliteracies do not follow a hierarchical order, but are interactive in complicated ways. Situated Practice emphasizes teachers' understanding of students' diversity and situating the meaning-making in real world contexts. Teachers need to create various teaching and learning practices to help students connect their own life experiences with their school experiences so that the literacy practices become "profoundly interactional" (Mondada and Doehler 2004, p. 501). For example, Mills (2006) introduced an Australian teacher who designed collaborative Claymation movie-making practices for her young CLD students. In this study, the Australian teacher emphasized "culture purposes" (p. 19) and movie themes that arose from "students' own interests" (p. 19). Through a collaborative Claymation movie-creating process (involving phases such as designing stories and setting up movie sets), students "moved from a school culture that focused predominately on monomodal writing, to a culture of visual, spatial, gestural and audio designing of digital movies characteristic of contemporary popular culture" (p. 27). The findings of Mills's (2006) study highlighted that the Claymation films practices enabled students to experience "culture shift(s)" (p. 27) by combining their different cultures to design Claymation movies, and engaging them "in a multimedia world" (p. 28). With guidance from the concept of Situated Practice, teachers stay on the lookout to capture students' diversity and situate the meaning-making in real-world contexts (The New London Group 1996), so that the literacy practices become profoundly interactional (Mondada and Doehler 2004).

Overt Instruction calls for teachers to cherish students' existing experiences and conduct collaborative activities with their students to develop their problem-solving skills (Cope and Kalantzis 2000, 2009). In this process, teachers can give tasks to their students and provide instructions to help them complete the tasks. Through a process 
referred to as scaffolding, as students gradually obtain new skills and knowledge, they gain a systematic and analytical understanding of their knowledge and become enabled to manage their learning goals by themselves (e.g., Cumming-Potvin 2007). In the scaffolding process, teachers also learn how to enact Overt Instruction and Situated Practice simultaneously. Taking Mills' (2006) research as an example again, in instructing students to design Claymation movies, the Australian teacher provided Overt Instructions to students on how to write stories properly. She provided direct instructions in each lesson to help her students understand what tasks they needed to complete. Through this instructional scaffolding, students used the knowledge taught by their teacher and mastered the Claymation movie-making skills by participating in collaborative activities with their peers. Therefore, the implications of the study pointed to the need for teachers to realize that "scaffolding in Situated Practice requires recognizing the complementary role of Overt Instruction" (Mills 2006, p. 29).

Critical Framing suggests teachers help "learners frame their growing mastery in practice (from Situated Practice) and conscious control and understanding (from Overt Instruction) in relation to the historical, social, cultural, political, ideological, and value-centered relations of particular systems of knowledge and social practice" (The New London Group, 1996, p. 21). Within the Critical Framing process, students can critically think, interpret, analyze, and express their own meanings in different learning practices. Students can also improve their interpretation skills when there are "important interactions with the learners' ability to access designs of meaning by relating meanings to their social and cultural contexts and purposes" (Mills 2006, p. 12).

At last, Transformed Practice refers to learners applying what they have learned through Situated Practice, Overt Instruction, and Critical Framing to new environments (Cope and Kalantzis 2000, 2009). To improve students' abilities to transform learned knowledge into different contexts, teachers need to create various opportunities for students to practice this knowledge transformation. For example, teachers can use role-play to help students learn to approach things from new angles. When students realize that their environment can influence their learning, "theory becomes reflective practice" (The New London Group, 1996, p. 87) because this awareness can guide them in dealing with different situations (Pahl and Rowsell 2006). Furthermore, Transformed Practice enables students to switch from "reproduction to innovation" (Mills 2008, p. 122) when they apply what they learned to solve new problems in literacy practices.

For a better understanding and employment of these four dimensions of multiliteracies, Kalantzis and Cope (2005) further developed them as: Experiencing, Conceptualizing, Analyzing, and Applying respectively. In terms of Experiencing, literacy learners should be aware of their previous knowledge and experiences. At the same time, they need to connect them with their newly acquired knowledge from new environments. Conceptualizing requires literacy learners to become conceptualizers in the process of changing from tacit knowledge to explicit knowledge (Cope and Kalantzis 2009, p. 185). Analyzing emphasizes literacy learners to functionally and critically examine and analyze knowledge and its meaning. At last, Applying signifies that learners are capable of properly and creatively applying what they have learned into their lives and surroundings in order to solve new problems and make their innovative contributions to the world (Cope and Kalantzis 2009). All in all, teachers can be inspired by and utilize 
multiliteracies pedagogy to create their own literacy practices and activities (Anstey and Bull 2006; Borsheim et al. 2008).

Second, multiliteracies focuses on the important role of multimodality in providing a variety of modes of meaning-making. In traditional literacy teaching, written language is the predominant form in the creation of any meaning (Cope and Kalantzis 2009). However, along with the rapid development of new media for communication, a wide range of modes became accessible to learners for a variety of communicational and representational potentials or affordances for meaning-making (Kress 2005). According to Jewitt (2006), multimodality refers to "[t]he repeated use of modes to represent and communicate particular meanings in specific social contexts" (p. 26). In this way, the notion of modal affordance demonstrates that modes are orchestrated in various manners such as becoming equivalent, complementary, or contradictory for meaning-making. Therefore, in today's fast-changing digital world, it is expected that students need to become critical users of digital technologies to communicate and participate in digital practices and cultures, which is often called digital literacy competence (Jenkins et al. 2006) as an essential twenty-first century skill.

Studies of young children's use of digital technologies also reveal how digital technologies such as mobile touchscreen devices including tablets and smartphones can play a significant role in developing students' multiliteracies (Neumann and Neumann 2017; Rowsell et al. 2013; Simpson et al. 2013). In particular, digital technologies are important tools for helping students including young CLD children to participate in making, remaking and transforming of meaning through the above-mentioned Designing process as active designers rather than passive consumers. This is because digital technologies offer diverse affordances of learning according to research on multiliteracies practices (Flewitt et al. 2015; Rowsell 2013).

Digital technologies provide students including even young children with creative opportunities to represent and communicate their own voice, opinion and feelings (Marsh 2011, 2014). Very young children, who have not yet learned to read and write in target language, can still develop their multiliteracies and become more motivated and confident through the act of meaning-making to make sense of the world and construct knowledge multimodally employing movement, images, gesture, music, mathematics, and speech (Kim and Rutgers 2018; Leander and Boldt 2012). A growing body of research also confirms that many young children often experience digital technologies (e.g., game players, laptop computers, smartphones, tablets) from a young age at home(Burke and Marsh 2013; Holloway et al. 2013 ).

\section{The study}

We adopted a qualitative case study methodology (Yin 2014) to deeply understand how Chinese teachers who have experienced multiliteracies and multimodality perceive and apply a pedagogy of multiliteracies in teaching young CLD children Chinese literacy in Canada. According to Denzin and Lincoln (2005), "qualitative researchers study things in their natural settings attempting to make sense of, or interpret, phenomena in terms of the meanings people bring to them" (p. 2). Moreover, a qualitative research "involves highly detailed rich descriptions of human behaviors and opinions" (Savenye and Robinson 2004, p. 1046) which enabled us to understand and interpret Chinese teachers' 
perceptions and experiences of multiliteracies in teaching young children Chinese literacy in Canada.

According to Robson (2002), a case study "is a strategy for doing research which involves an empirical investigation of a particular contemporary phenomenon within its real-life context using multiple sources of evidence" (p. 178). Therefore, considering the definition of case study as well as our aim to deeply understand Chinese teachers' perceptions and implementations of multiliteracies in teaching young children Chinese literacy in a Canadian teaching context, a case study provides a "unique example of real people in real situations" (Cohen et al. 2013, p. 289).

In order to obtain rich information for the research, purposeful sampling was employed (Patton 2002) which calls for the researcher to select participants based on the particular aims of the study (Coyne 1997). Therefore, according to our research goals of finding Chinese teachers who have experienced multiliteracies education and are teaching young children Chinese in Canada, the following selection criteria were made to look for ideal participants for our research: (a) Chinese teachers who are teaching young CLD children Chinese literacy in Canada, (b) Chinese teachers who have relevant education or training on multiliteracies theory and pedagogy, and (c) Chinese teachers who are interested in sharing their experiences and suggestions of applying multiliteracies in literacy teaching. After receiving the ethics approval, we started to contact Chinese schools in Canada to look for possible Chinese teachers who could fulfill the selection criteria. Finally, we recruited two Chinese teachers, Susan and Jane (pseudonyms) who fulfilled the three criteria and agreed to participate in our research. They studied multiliteracies and multimodality in their master programs in Canada and had more than 5 years of teaching experiences both in China and Canada.

\section{Data collection and analysis}

According to Yin (2014), a case study requires multiple sources of data to conduct a narrative analysis to configure the diverse elements of data into "a unified whole in which each element is connected to the central purpose of the action" (Polkinghorne 1995, p. 11). We utilized three data sources to interpret through narrative analysis: interviews, reflective writings, and curriculum materials. Each method of data collection "is useful for providing a different perspective on the topic of interest," and "contributes to a more complete picture of the scene of interest" (Eisenhart 1988, p. 106). For instance, interviews and reflective writing were used to help the participants reflect on their experiences and craft their narratives. An experience-centered narrative analysis focuses more on meaning and understanding about a specific person or situation (Bold 2012). Through this experience-based data analysis procedure aiming to organize the data elements into a coherent developmental account (Polkinghorne 1995) and configure them into a unified story, we used a constant comparison method (CCM) (Glaser and Strauss 1967). CCM is "a method of analyzing qualitative data where the information gathered is coded into emergent themes or codes" (Hewitt-Taylor 2001, p. 39) allowing us to "combine inductive category coding with a simultaneous comparison of all social incidents observed" (Goetz and LeCompte 1981, p. 58).

For conducting the CCM, all recorded Chinese interviews were transcribed and translated into English written texts with pseudonyms. Transcription is a vital step 
which "can provide important detail and an accurate verbatim record of the interview" (Cohen et al., 2011, p. 537). To make sure of the translation quality, we shared English transcripts with participants to ensure that their thoughts were correctly described as member checking. Then we started the coding process with open coding (Strauss and Corbin 1990) which is "the process of breaking down, examining, comparing, conceptualizing, and categorizing data" (p. 61) by meticulously looking through all data sources to respond to our research question. Each code was used to "represent a theme or idea with which each part of the data is associated" (Hewitt-Taylor 2001, p. 39). For example, one code was named "professional study of multiliteracies" with its definition referring to any related professional learning experiences of multiliteracies theory and pedagogy. In the end of the open coding process, we had generated around forty open codes in total. Then, we conducted the axial coding process (Strauss and Corbin 1990) in which we compared, sorted out, and tried to find connections between the open codes and then generated higher level axial codes. For instance, one axial code was "multiple literacy teaching resources" which consisted of several open codes such as "technology and music to teach Chinese literacy," "Rope for playing games," and so on. Next, all axial codes were compared with each other and merged to form categories. For example, a category called "multiliteracies practices in Chinese literacy teaching" contained the axial codes of "innovative Chinese literacy teaching methods," "instructions," "developing critical thinking abilities," and so on.

We also conducted peer debriefings to validate the themes. According to Lincoln and Guba (1985), peer debriefing "is a process of exposing oneself to a disinterested peer in a manner paralleling an analytical session and for the purpose of exploring aspects of the inquiry that might otherwise remain only implicit within the inquirer's mind" (p. 308). Peer debriefing enables researchers to overcome biases and enhance the credibility of the research by providing "an external check on the inquiry process" (Lincoln and Guba, p. 301).

\section{Finding: appropriation of affordances of multiliteracies}

When we specially asked about when and how Susan and Jane started to learn about multiliteracies, Susan responded in her first interview, "I started to learn about multiliteracies in my graduate studies in which I had classes that were about multiliteracies theory and pedagogy" (December 5, 2016). Susan also noted that she was teaching young children Chinese during her master's program: "the classes I had about multiliteracies were mainly in the ECE (early childhood education) area, which was helpful to my practical teaching experiences" (December 5, 2016). In her interview, Jane also acknowledged the importance of her learning experiences of multiliteracies: "From my master study in Canada I started to know multiliteracies and multimodality" (December 6, 2016). While doing her master studies, Jane got a chance to teach young children Chinese in a local Chinese school, so she shared, "I found it benefits me a lot when I can apply what I learned from classes into my teaching environments as I was able to better understand how I can put multiliteracies theory and pedagogy into my own teaching setting" (Reflective Writing, January 12, 2017). Hence, it was revealed that the two Chinese teachers were able to access multiliteracies theories and pedagogies due to their Professional Master's program in Canada. 


\section{Perceiving and designing the multiplicity of cultures and meaning-making channels}

Further, it was acknowledged that learning from the Professional Master's program allowed Susan and Jane to recognize and understand affordances of multiliteracies in Chinese literacy teaching contexts in Canada. Susan admitted that she started to pay more attention to the issue of diversity in the early multiliteracies practices of young CLD children. For example, she shared in her first interview, "multiliteracies are developed to deal with the diversity trend in our society. One important reason is that multiliteracies provides creative ideas to facilitate teacher's teaching methods and ways in their own classrooms upon students' needs and interests" (December 5, 2016). Similarly, in her reflective writing, Susan confirmed her views about multiliteracies, "[m]y students came from different culture and language backgrounds, which brought so many differences and challenges in my teaching. Multiliteracies inspired me to come up with diverse ways to catch their different learning interests and needs" (January 6, 2017).

Jane also admitted that "multiliteracies enable students to communicate with others and express their thoughts through different ways or platforms, which is not only restricted to print or written forms" (Reflective Writing, January 12, 2017). According to Jane's understanding of multiliteracies, she considered multiple modes of meaning-making and communicating including speech, gesture, images, videos, songs, and other non-verbal modes (Rowsell 2013). To quote Jane,

From my own development and studying experiences in China, I could always remember that my teachers mainly relied on print-based materials to teach our reading and writing. After I was first exposed to the concepts and theories of multiliteracies and multimodality, the first feeling was that multiliteracies pedagogy could help prepare our students for their daily lives in a changing world, to help them develop practical and necessary literacy skills for their future. (December 6, 2016)

Jane explored and utilized technological and cultural resources that her students could draw upon. For example, she brought her laptop to her class and recommended every Wednesday as their Chinese Cartoon Day. On that day, drawing upon her students' interests, experiences, and needs, Jane played a famous Chinese cartoon called XI YANG YANG YU HUI TAI LANG meaning Sheep Xi with Wolf Gray which had more than 500 episodes happening between sheep and wolf groups. Susan also used online videos to teach Chinese poems. The videos guided her students to watch, listen, comprehend, and make sense of poems which extended the literacy learning possibilities beyond traditional print-based texts.

\section{Perceiving and designing the interconnectedness of multiliteracies pedagogies}

Drawing upon multiliteracies pedagogies, Susan and Jane often put their effort in connecting Overt Instruction with Situated Practice. For instance, Susan tried to connect students' prior experiences and knowledge with Chinese literacy learning so that during the Mid-Autumn Chinese Festival, she designed the activity of making a paper lantern to situate her students in participating in authentic cultural activities. Also, she 
encouraged her students to write their wishes on their lanterns and draw Chinese written couplets that they could stick on their house doors during the festival. Her Overt Instructions helped her students understand what tasks they needed to complete. Susan reported in her reflective writing that "many students were happily involved in these activities, and many of them made incredible lanterns or created amazing written couplets by themselves." Instead of focusing mainly on Overt Instruction, therefore, her literacy teaching demonstrated her understanding of the complementary role of Overt Instruction in Situated Practice (Mills 2006).

Most importantly, interviews with Susan and Jane including their reflective writings and curriculum materials also confirmed that both Susan and Jane paid attention to higher order thinking (e.g., comprehension, critical thinking) beyond teaching the technical skills of reading and writing. In other words, they started to recognize and understand the complex phenomena of young CLD children's multiliteracies practices. This is similar to what The New London Group (1996) stated that literacy teaching needed to be viewed holistically as a multiple, interconnected, continuous, dynamic, and emergent process.

Susan's reflective writing reveals that "after I learned about multiliteracies, I held the belief that reading and writing should not be regarded as the dominant aspects of literacy teaching, students need to develop other literacy abilities such as comprehension and expression skills as well" (January 6,2017). Jane shared in her reflective writing that "[m]ultiliteracies also teach me to realize a wide scope of literacy teaching and learning. Besides reading the textbooks and writing characters, teachers should pay attention to develop students' different literacy abilities, such as critical thinking abilities, meaning-making and expressing" (January 12, 2017). For instance, Jane designed a poetic role-play practice to help her students apply the knowledge they learned to solve new problems in their studies. She also aimed to teach her students critical thinking about the four seasons in Beijing as indicated in her lesson plan (see Fig. 1). Jane started her class with an inquiry time to reflect on their favorite seasons. Then she used an iPad to allow her students to access pictures and videos about the scenery of four seasons in Beijing. In addition, Jane designed a drawing activity for her students to encourage them to represent and communicate their favorite seasons and activities they liked to do. Further, Jane proposed a speaking activity to allow students to speak about their favorite season in Chinese and the reasons why they chose a particular season.

Jane also noted that reading a series of stories was effective in helping her students systematically develop their critical thinking abilities. For example, she provided a series of eight story books about a group of rats living in a beautiful village. The stories were connected with each other and were gradually developed "to develop students' critical thinking abilities" (Reflective Writing, January 12, 2017). Figure 2 shows two stories from this series, which talked about a mysterious staircase and an adventure in the mountains. By reading the first two books to students, she enabled her students to, as the New London Group stated, "gain the necessary personal and theoretical distance from what they have learned" (p. 87). Then, by showing students the pictures/images in the story books, she facilitated her students to "constructively critique it, account for its cultural location, creatively extend and apply it," and "eventually innovate on their own" (The New London Group 1996, p. 87) by coming up with their diverse thoughts to predict what happened next in the story. 


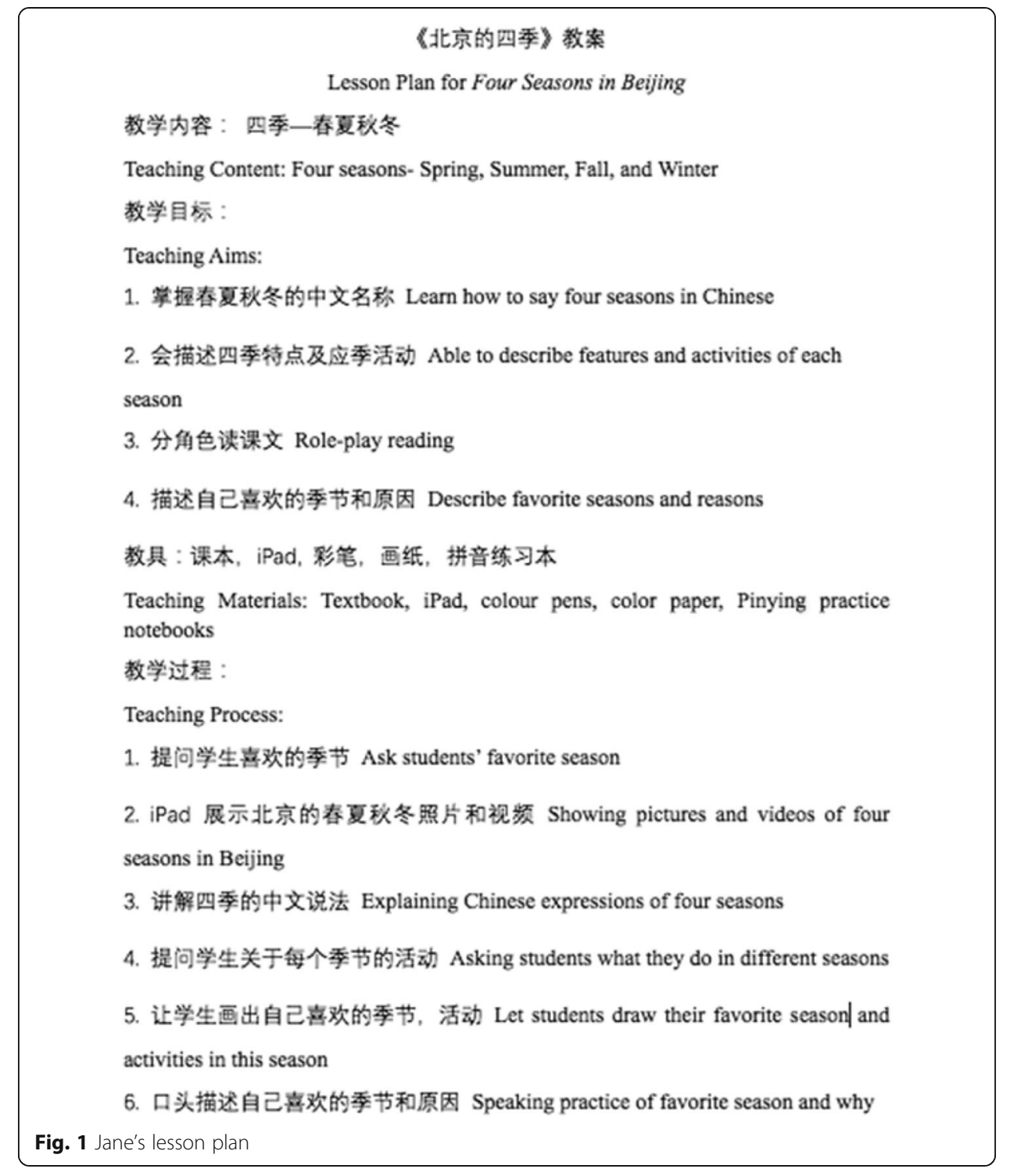

Similarly, Susan designed a debate activity of The Great Wall to promote her students' critical thinking. In her reflective writing, she noted the importance of developing critical abilities for young children in literacy learning:

When I was a young student in China, my class had many students. Teachers didn't have enough time to listen to each student's thoughts and they would not be happy if students came up with different opinions than their teachers. Under that kind of teaching environment, every student behaved like factory products, as everyone was equipped with the same knowledge and expressed the same thoughts in the same way. When I grew up, I realized how important it is for a child to have the rights and abilities to speak their own thoughts and show different opinions. Therefore, in my teaching, I gave my students enough time and opportunities to let them voice their own opinions. For example, after I taught them about the Great Wall, I designed a small debate about the Great Wall for them. I encouraged them to 


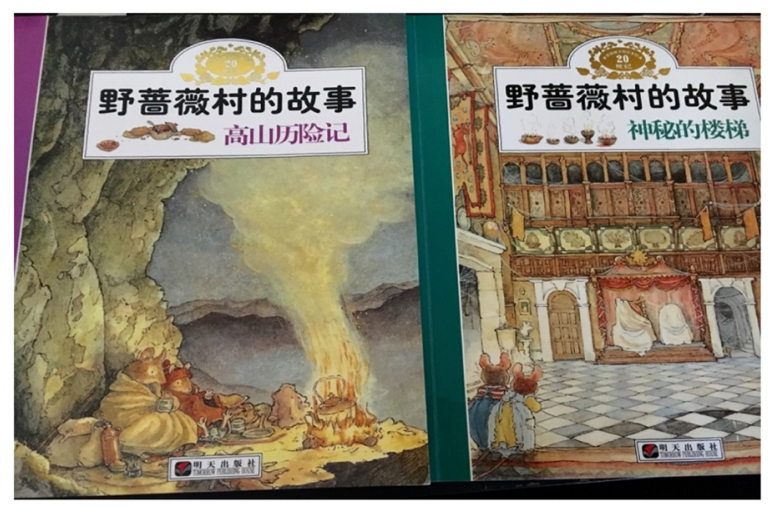

Fig. 2 A series of stories

express their various thoughts about this large construction in China. This debate was successful as it encouraged students to bravely express their different opinions about the Great Wall. Some students thought it was important to defend the motherland while other students argued the Great Wall wasted lots of money collected from poor people and many families were separated due to its timeconsuming construction. I cherished all their views and encouraged them to continually question and think critically about their lives and the world. (Reflective writing, January 6, 2017)

According to Susan's first interview, "students were engaged in different Chinese literacy practices and focused more on my teaching" (December 5, 2016). In a similar manner, Jane also reported in her first interview that by implementing multiliteracies, her students "get motivated and can build confidence in literacy learning" (December 6 , 2016). Their experiences of multiliteracies pedagogies revealed that they were able to provide young CLD children with diverse learning experiences and engage them actively in Chinese literacy learning.

\section{Discussion and implications}

Susan and Jane's interviews, curriculum materials, and reflective writings reveal that Susan and Jane appropriated affordances of multiliteracies theories and pedagogies that they learned in their 2-year Professional Master's program in Canada for young culturally and linguistically diverse (CLD) students. They both expressed the importance and positive outcomes of implementing multiliteracies in their Chinese literacy teaching contexts. By designing meaningful literacy activities discussed in the previous session, Susan and Jane revealed that they were strongly motivated to facilitate their students to recognize, value, and promote the multiplicity of cultures and meaning-making channels. In particular, Susan focused more on multiliteracies in dealing with the multiplicity of cultures in her class, while Jane paid more attention to the multiplicity of meaning-making channels/resources/modes for her young CLD students.

Taken together, their stories allow us to understand two affordances of multiliteracies in Chinese literacy teaching in Canada: (1) perceiving and designing the multiplicity of cultures and meaning-making channels, and (2) perceiving and designing the interconnectedness of multiliteracies pedagogies. Examining the four dimensions of 
multiliteracies pedagogies of two Chinese teachers' literacy practices provides us with a better understanding of their perception and implementation of multiliteracies practices. In particular, using digital technologies, Susan and Jane made an effort to connect Situated Practice with Overt Instruction by incorporating students' interests and life experiences outside the classroom.

For this, our findings highlighted how they actively perceived and appropriated available semiotic resources (as Available Designs, The New London Group 1996) including digital devices (e.g., iPads, on-line videos) in a purposeful and integrated manner to incorporate their students' cultures, interests, and needs. In other words, by meaningfully connecting their students' out-of-school experiences with classroom literacy learning, Susan and Jane demonstrated their efforts to design multiliteracies practices that were relevant and authentic to situate their young CLD children in meaningful literacy activities. Thus, in keeping with recent studies by Flewitt et al. (2015), they did not focus on teaching how to operate iPad, videos, or other digital devices which are increasingly available to young children in their homes. Rather, Susan and Jane acknowledged the importance of student agency in participating in the process of Design; this is a transformation process where their students became active co-designers who could appropriate their own cultures and semiotic tools (as Available Designs) to co-design meaningful multiliteracies activity resulting in constructing multimodal artifacts.

As such, Susan and Jane valued students' diversity and engaged them in different Chinese literacy activities, which made it possible for their students to become, as Kalantzis and Cope (2005) also said, active meaning makers or designers in their literacy learning and construct multimodal artifacts. In this process of "designing" (Cope and Kalantzis 2009), Susan and Jane were not just consumers and users of pre-determined literacy curricula, but designers and co-creators of literacy curricula through orchestrating available multiple semiotic resources and appropriating the affordances of multiliteracies.

Rather than relying mainly on written textbooks, they started to use multiple semiotic resources. This also shows that teachers' understanding of multiliteracies is improved as a result of pursuing multiliteracies graduate studies as teacher professional development. The way of what they used as semiotic resources and how they used semiotic resources changed. For example, as their teaching practices, Susan and Jane took their students' diverse learning interests (e.g., making crafts) and learning needs (e.g., becoming active meaning makers, maximizing diverse communication and identity options) into consideration when they designed multiliteracies practices.

However, we found that most of their multiliteracies practices focused on the Situated Practice and Overt Instruction dimensions of the multiliteracies pedagogies with a few instances of the Critical Framing and Transformed Practice dimensions. This finding can relate to their challenges that Susan and Jane both encountered in their multiliteracies teaching. It is argued that merely being exposed to innovative instructional strategies and pedagogies does not necessarily lead to the acquisition of innovative instructional strategies and pedagogies. The process of "designing" in multiliteracies needs to be a transformative process. This transformation as noted by Rowsell et al. (2008) allows teachers to become active agents as they make choices about their own learning to impact student learning.

To respond to this challenge, Susan provided recommendations for teachers in her reflective writing, 
For teachers who want to implement multiliteracies, attending a professional program on multiliteracies is a good start for them, as they can build a systematic knowledge of multiliteracies and multimodality. Meanwhile, learning from professors and peers in the professional programs can also inspire and facilitate teachers' teaching in practical teaching contexts. (May 12, 2017).

Jane also expressed in her reflective writing that school boards need to provide teachers with an opportunity to attend professional workshops or training programs to help them learn more about the implementations of multiliteracies and multimodality. In light of this, it is also recommended for teacher educators and policy makers to provide ongoing learning opportunities (Kayi-Aydar 2015; Kosnik et al. 2013; Rowsell, Kosnik, and Beck 2008) with teachers who could become multiliteracies designers in understanding, designing, and implementing multiliteracies practices working with culturally and linguistically diverse (CLD) children through digital technologies.

\section{Highlights}

- Multiliteracies enabled two Chinese teachers to work with CLD students in Canada.

- Teachers appropriated affordances of multiliteracies for Chinese literacy teaching.

- This implies the importance of teacher professional development.

Authors' contributions

Both authors read and approved the final manuscript.

Competing interests

The authors declare that they have no competing interests.

\section{Publisher's Note}

Springer Nature remains neutral with regard to jurisdictional claims in published maps and institutional affiliations.

Received: 3 July 2018 Accepted: 4 January 2019

Published online: 18 January 2019

\section{References}

Albert, W. (2011). Gaps in current Chinese teaching materials and methods. Retrieved July 5, 2016, from http://laowaichinese. net/gaps-in-current-chinese-teaching-materials-and-methods.htm.

Anstey, M., \& Bull, G. (2006). Teaching and learning multiliteracies: changing times, changing literacies. Newark: International Reading Association.

Bold, C. (2012). Using narrative in research. London: Sage.

Borsheim, C., Merritt, K., \& Reed, D. (2008). Beyond technology for technology's sake: advancing multiliteracies in the twentyfirst century. The Clearing House: A Journal of Educational Strategies, Issues and Ideas, 82(2), 87-90.

Burke, A., \& Marsh, J. (2013). The changing landscapes of children's play worlds. In A. Burke \& J. Marsh (Eds.), Children's virtual play worlds: Culture, learning, and participation (Vol. 58, pp. 1-10). New York: Peter Lang.

Cohen, L. Manion, L., \& Morrison, K. (2011). Research methods in education. London, UK: Routledge.

Cohen, L., Manion, L., \& Morrison, K. (2013). Research methods in education. Routledge.

Cole, D. R., \& Pullen, D. L. (2009). Multiliteracies in motion: current theory and practice. Routledge.

Cope, B., \& Kalantzis, M. (Eds.). (2000). Multiliteracies: Literacy learning and the design of social futures. Victoria: Macmillan.

Cope, B., \& Kalantzis, M. (2009). Multiliteracies: new literacies, new learning. Pedagogies: An international Journal, 4(3), $164-195$.

Cope, B., \& Kalantzis, M. (2014). The powers of literacy: a genre approach to teaching writing. London: Routledge.

Coyne, I. T. (1997). Sampling in qualitative research. Purposeful and theoretical sampling; merging or clear boundaries? Journal of Advanced Nursing, 26(3), 623-630.

Cumming-Potvin, W. (2007). Scaffolding, multiliteracies, and reading circles. Canadian Journal of Education/Revue canadienne de l'éducation, 483-507.

Denzin, N. K., \& Lincoln, Y. S. (2005). Handbook of qualitative research. London: Sage Publications.

Eisenhart, M. A. (1988). The ethnographic research tradition and mathematics education research. Journal of Research in Mathematics Education, 19(2), 99-114.

Flewitt, R., Messer, D., \& Kucirkova, N. (2015). New directions for early literacy in a digital age: the iPad. Journal of Early Literacy Research, 15(3), 289-310.

Glaser, B. G., \& Strauss, A. L. (1967). The discovery of grounded theory. Chicago: Aldane.

Goetz, J. P., \& LeCompte, M. D. (1981). Ethnographic research and the problem of data reduction. Anthropology and Education Quarterly, 12, 51-70.

Hamston, J. (2006). Pathways to multiliteracies: Student teachers' critical reflections on a multimodal text. Australian Journal of Language and Literacy, 29(1), 38-51. 
Hanban, X. (2015). Confucius institute and classrooms. Confucius institute/classroom. Retrieved July 12, 2016, from http:// www.hanban.edu.cn/confuciousinstitutes/node_10961.htm

Hewitt-Taylor, J. (2001). Use of constant comparative analysis in qualitative research. Nursing Standard, 15(42), 39-42.

Holloway, D., Green, L., \& Livingston, S. (2013). In LSE, EU Kids Online (Ed.), Zero to eight. Young children and their internet use. London: Retrieved on October 20, 2018 from http://www.open.edu/openlearn/ocw/pluginfile.php/559256/mod_ resource/content/3/Zero\%20to\%20Eight.pdf.

Jenkins, H., Clinton, K., Purushotma, P., Robinson, AJ., \& Weigel, M, (2006). Confronting the challenges of participatory culture: Media education for the 21st Century. MacArthur Foundation. Retrieved October 20, 2018, from https://www.macfound. org/media/article_pdfs/JENKINS WHITE PAPER.PDF

Liu, Y., \& Bebbington, T. (2012). Retrieved Jan. 10, 2019, from https://dspace.library.uvic.ca/bitstream/handle/1828/4012/ WCILCOS2012paperUVic_Ying\%26Tina.pdf?sequence=1\&isAllowed=y

Jewitt, C. (2006). Technology, literacy, learning: a multimodal approach. London \& New York: Routledge.

Jin, L., \& Cortazzi, M. (1998). Dimensions of dialogue: large classes in China. International Journal of Educational Research, 29(8), 739-761.

Kalantzis, M., \& Cope, B. (2005). Learning by design. Common Ground.

Kalantzis, M., \& Cope, B. (2012). Literacies. Victoria: Cambridge University Press.

Kalantzis, M., \& Cope, B. (2017). Regimes of literacy. In M. Hamilton, R. Heydon, K. Hibbert, \& R. Stooke (Eds.), Negotiating spaces for literacy learning: multimodality and governmentality (pp. 15-24). London: Bloomsbury.

Kayi-Aydar, H. (2015). Teacher agency, positioning, and English language learners: voices of pre-service classroom teachers. Teaching and Teacher Education, 45, 94-103.

Kim, M.S. (2013). Teachers as learning designers through teachers' design thinking. In N. Rummel, M. Kapur, M. Nathan \& S. Puntambekar (Eds.), In Proceedings of the 10th International Conference on Computer Supported Collaborative Learning (pp.493-494). Madison, Wisconsin, USA: International Society for the Learning Sciences.

Kim, M.S., \& Rutgers, J. (2018). Supporting experiential learning through an online learning community. 2018 Learning Outcome Conference.

Kosnik, C., Rowsell, J., Williamson, P., Simon, R., \& Beck, C. (2013). Literacy teacher educators: preparing teachers for a changing world. Rotterdam: Sense Publishers.

Kress, G. (2005). Multimodality, "reading", and "writing" for the 21 $1^{\text {st }}$ century. Discourse: Studies In The Cultural Politics of Education, 26(3), 315-331.

Kuby, C. R., \& Vaughn, M. (2015). Young children's identities becoming: exploring agency in the creation of multimodal literacies. Journal of Early Literacy Research, 15(4), 433-472.

Leander, K., \& Boldt, G. (2012). Rereading "a pedagogy of multiliteracies": bodies, texts, and emergence. Journal of Literacy Research, 45(1), 22-46

Li, H. (2013). Teaching Chinese literacy in the early years: a comparison of L1 and L2 preschool classrooms in Shenzhen and Singapore. Asia-Pacific Journal of Research in Early Childhood Education, 7(3), 19-43.

Li, H., Rao, N., \& Tse, S. K. (2012). Adopting western pedagogies into teaching Chinese literacy: comparison of Hong Kong. Shenzhen and Singapore preschool classrooms. Early Education and Development, 23(4), 1-19.

Li, H., Wang, X. C., \& Wong, J. M. S. (2011). Early childhood curriculum reform in China: perspectives from examining teachers' beliefs and practices in Chinese literacy teaching. Chinese Education \& Society, 44(6), 5-23.

Lincoln, Y., \& Guba, E. (1985). Naturalistic inquiry. Beverly Hills: Sage.

Makin, L., Diaz, C. J., \& McLachlan, C. (2007). Literacies in childhood: changing views, challenging practice. Elsevier Australia.

Marsh, J. (2011). Young children's literacy practices in a virtual world: establishing an online interaction order. Reading Research Quarterly, 46(2), 101-118.

Marsh, J. (2014). Researching young children's literacy practices in online virtual worlds. In P. Albers, T. Holbrook, \& A. Flint (Eds.), New methods of literacy research (pp. 196-209). New York: Routledge.

Mills, K. A. (2006). Critical framing in a pedagogy of multiliteracies. In Proceedings Australian Literacy Educators' Association/ Australian Association of the Teaching of English National Conference 2006: Voices, Vibes, Visions. Hearing the Voices, Feeling the Vibes, Capturing the Visions.

Mills, K. A. (2008). Transformed practice in a pedagogy of multiliteracies. Pedagogies: An International Journal, 3(2), 109-128.

Mondada, L., \& Doehler, S. P. (2004). Second language acquisition as situated practice: task accomplishment in the French second language classroom. The Modern Language Journal, 88(4), 501-518.

National Household Survey. (2011). Immigration and Ethnocultural diversity in Canada. Statistics Canada Retrieved May 2, 2016, from https:/www12.statcan.gc.ca/nhs-enm/2011/as-sa/99-010-x/99-010-x2011001-eng.cfm.

Neumann, M. M., \& Neumann, D. (2017). The use of touch-screen tablets at home and preschool to foster emergent literacy. Journal of Early Literacy Research, 17(2), 203-220.

Pahl, K., \& Rowsell, J. (Eds.). (2006). Travel notes from the new literacy studies: instances of practice. Clevedon: Multilingual Matters Ltd.

Patton, M. Q. (2002). Qualitative research \& evaluation methods. Thousand Oaks: Sage.

Polkinghorne, D. E. (1995). Narrative configuration in qualitative analysis. Qualitative Studies in Education, 8(1), 5-23.

Robson, C. (2002). Real world research: a resource for social scientists and practitioner-researchers. Oxford: Blackwell.

Rowe, D. W. (2013). Recent trends in research on young children's authoring. In J. Larson \& J. Marsh (Eds.), The sage handbook of early childhood literacy (2nd ed., pp. 423-447). London: Sage.

Rowsell, J., Kosnik, C., \& Beck, C. (2008). Fostering multiliteracies pedagogy through preservice teacher education. Teaching Education, 19(2), 109-122.

Rowsell, J. (2013). Working with multimodality: rethinking literacy in a digital age. New York: Routledge.

Rowsell, J., Saudelli, M., Scott, R., \& Bishop, A. (2013). iPads as placed resources: forging community in online and offline spaces. Lanquage Arts, 90(5), 351-360.

Savenye, W. C., \& Robinson, R. S. (2004). Qualitative research issues and methods: an introduction for educational technologists. In D. H. Jonassen (Ed.), Handbook of research on educational communications and technology (pp. 10451071). Mahwah: Lawrence Erlbaum Associates.

Simpson, A., Walsh, W., \& Rowsell, J. (2013). The digital reading path: researching modes and multidirectionality with iPads. Literacy, 47(3), 123-129.

Strauss, A., \& Corbin, J. (1990). Basic of qualitative research: Grounded theory procedures and techniques. Newbury Park: Sage Publications. The New London Group (NLG). (1996). A pedagogy of multiliteracies: designing social futures. Harvard Educational Review, 66, 60-92. Yin, R. K. (2014). Case study research: Design \& Methods (5th ed.). Thousand Oaks: Sage. 